\title{
М.Е. Кадомцева
}

\section{ИССЛЕДОВАНИЕ МЕЖРЕГИОНАЛЬНЫХ РАЗЛИЧИЙ РАЗВИТИЯ СТРАХОВАНИЯ СЕЛЬСКОХОЗЯЙСТВЕННЫХ РИСКОВ В РАСТЕНИЕВОДСТВЕ}

\begin{abstract}
Фрагментарность российской экономической системы в пространственном аспекте является одной из причин, сдерживающих развитие национального агропродовольственного комплекса. Важнейшим элементом данной системы является страхование сельскохозяйственных рисков, в том числе осуществляемое на основе государственной поддержки. Развитие процессов субсидируемого страхования сельскохозяйственных рисков в регионах идет весьма неравномерно, и данная проблема наращивает свою значимость, потому как задача продовольственного самообеспечения страны все больше уходит в межрегиональное пространство. Целью настоящего исследования является анализ региональных особенностей развития и уровня использования страхования сельскохозяйственных рисков с государственной поддержкой, а также определение фракторов, детерминирующих процессы региональной дифференциации. С помощью корреляционно-регрессионного метода проанализированы основные индикаторы, характеризующие сельскохозяйственное страхование с государственной поддержкой с 2016 по 2018 г., и исследована причинно-следственная связь между показателями страхования, экономическими показателями сельскохозяйственного производства, ресурсного потенциала и бюджетного субсидирования субъектов РФ. Проведенный анализ послужил основой для выявления факторов, оказывающих наибольшее влияние на использование сельхозтоваропроизводителями услуг субсидируемого страхования сельскохозяйственных рисков в растениеводстве. Доказана необходимость учета регионального аспекта при разработке стратегии развития сельскохозяйственного страхования.

Ключевые слова: страхование, сельское хозяйство, растениеводство, продовольственная безопасность, субсидия, региональная диффреренциация, механизм.
\end{abstract}

Введение. В условиях реализации стратегии социально-экономического развития России, нацеленной на внутреннее самообеспечение, одно из центральных мест в экономической безопасности страны стала занимать продовольственная безопасность. Фундаментом ее обеспечения является устойчивое развитие национального агропродовольственного комплекса (АПК) под влиянием глобальных вызовов, в число которых входят геополитическая нестабильность, неустойчивость развития мировой экономики, усиление глобальной конкуренции, риски, связанные с технологическим отставанием, характерные для сельскохозяйственного производства природно-климатические риски, в том числе вызванные глобальными климатическими изменениями [1-3].

\section{() Кадомцева М.Е., 2019}

Кадомцева Марина Евгеньевна - канд. экон. наук, ст. науч. сотрудник лаборатории стратегии развития институциональной среды агропромышленного комплекса ФГБУН «Институт аграрных проблем Российской академии наук», e-mail: kozyreva_marina_@mail.ru. 
Применительно к агропродовольственному комплексу академиком РАН Э.Н. Крылатых разработана методика изучения рисков, согласно которой выделены 25 стратегических рисков, сгруппированных по пяти основным группам: природно-климатические, погодные, индивидуальные (социальные) риски; экономические, производственные и управленческие риски; рыночные риски; инновационные риски [4]. Действительно, на всех этапах своего развития сельскохозяйственная отрасль, особенно подотрасль растениеводства, которая в настоящее время является локомотивом сельхозпроизводства, оставались чрезвычайно зависимыми от природно-климатических условий (рис. 1). Причем международные группы исследователей справедливо замечают нарастающее влияние негативных природно-климатических факторов на устойчивость региональных агропродовольственных систем [5, с. 40].

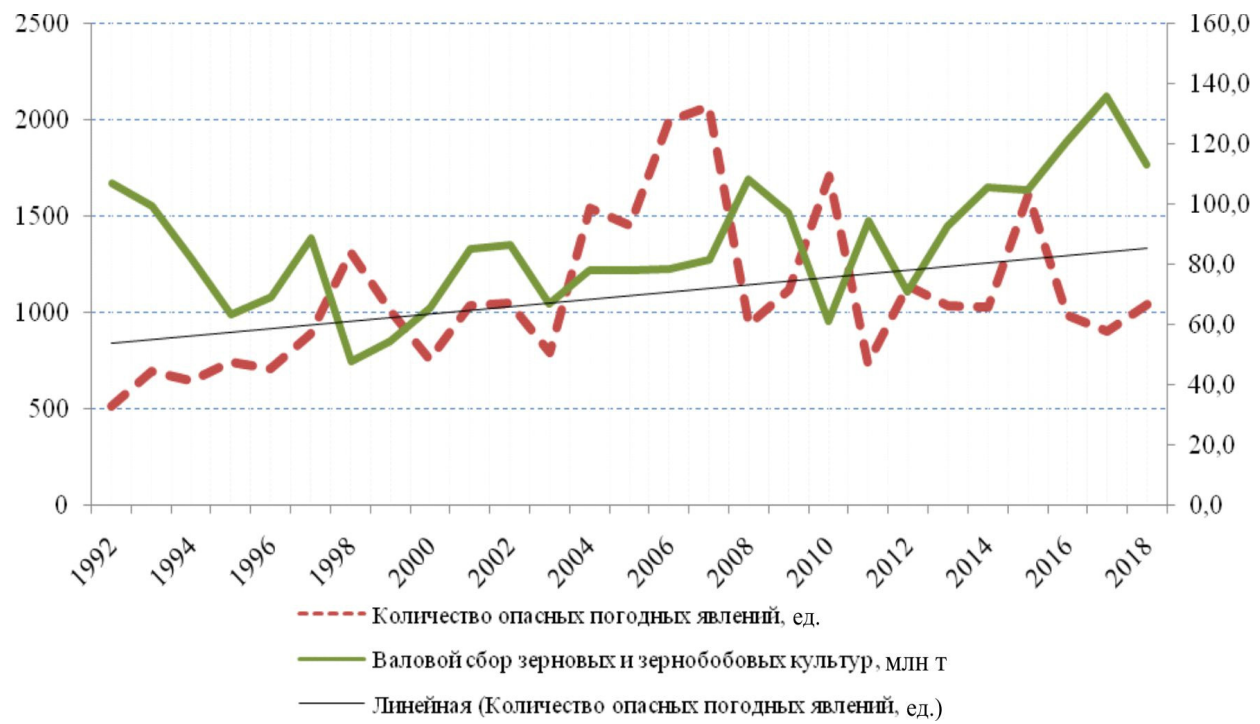

Рис. 1. Динамика показателей роста опасных погодных явлений на территории

Российской Федерации (ед.) и валового сбора зерновых и зернобобовых культур (млн т) [6]

Страхование сельскохозяйственных рисков является составной частью организационно-экономического механизма управления развитием национального агропродовольственного комплекса. Его следует рассматривать как институт, способствующий формированию предпосылок финансовой устойчивости сельхозпроизводителей в случае возникновения рисков. Развитая страховая система с государственной поддержкой оказывает значительное влияние на доходность сельхозтоваропроизводителей и сальдированный финансовый результат подлежащих страхованию подотраслей сельского хозяйства региона. Однако охват сельскохозяйственного производства агрострахованием на основе государственной поддержки явно является недостаточным. 
Количество субъектов РФ, участвующих в реализации субсидируемого страхования, с каждым годом сокращается: в 2016 г. приняли участие в страховании урожая сельскохозяйственных культур с государственной поддержкой 40 субъектов, в 2017 г. - 32, в 2018 г. количество субъектов снизилось до 26. Целевой показатель - удельный вес посевной (посадочной) площади застрахованных культур упал с 17,6 \% в 2014 г. до 1,5 \% в 2018 г., а число сельхозтоваропроизводителей, до которых была доведена субсидия, снизилась с 5827 до 209 ед. соответственно [7, 8]. Таким образом, в контексте реализации стратегии, нацеленной на обеспечение продовольственной безопасности, выделяемые дополнительные бюджетные средства на развитие сельского хозяйства субъектам РФ, без эффективно работающей страховой системы, остаются незащищенными. Кроме того, региональная структура страхового рынка России на протяжении последних лет демонстрирует особенно высокую дифференциацию распределения страховых премий по территории страны.

Проблема снижения неравномерности охвата сельхозпроизводителей услугами страхования приобретает значимость, так как механизм продовольственного самообеспечения страны уходит все больше в межрегиональное пространство. Ряд отечественных авторитетных исследователей справедливо замечают, что для совершенствования агропродовольственной политики, определения приоритетов при разработке государственных целевых программ и обосновании уровня и мер государственной поддержки товаропроизводителей, оказания прямой продовольственной помощи потребителям необходима оценка регионов по объективным природно-климатическим, демографическим и прочим параметрам, а также комплексный анализ целевых, результирующих показателей, производственных возможностей регионов, выявление причин межрегиональных различий [9, с. 62]. По нашему мнению, исследование региональной дифференциации развития субсидируемого страхования сельскохозяйственных рисков, как одной из составляющих системы институтов обеспечения продовольственной безопасности, представляет особый интерес. Учет региональных особенностей при формировании финансово-экономического механизма развития АПК позволит эффективно использовать потенциальные возможности с целью устойчивого и сбалансированного развития региональных агросистем, наращивания производственного потенциала и конкурентоспособности регионов [10].

Методы исследования. Исследование региональной дифференциации субсидируемого страхования сельскохозяйственных рисков в подотрасли растениеводства построено в первую очередь на анализе количественных показателей, характеризующих эффективность развития сельскохозяйственного страхования в регионах, и их сопоставлении с качественными преобразованиями институционального характера, происходящими в социально-экономическом пространстве страны. Информационная база исследования включа- 
ла материалы Федерального статистического наблюдения, ежегодные отчеты Национального союза агростраховщиков, данные Росгидромета, а также оперативную информацию о состоянии субсидируемого сельскохозяйственного страхования, представленную на сайте ФГБУ «ФАГПССАП».

Исследование дисбаланса развития страхования в растениеводстве осуществлено на основе анализа результирующего показателя - удельный вес посевных (посадочных) площадей застрахованных культур в региональном разрезе за 2016-2018 гг. При этом нами исключены из рассмотрения такие города, как Москва, Санкт-Петербург, Севастополь, автономные округа, а также ряд регионов, которые ввиду низких объемов сельскохозяйственного производства не оказывают значимого влияния на обеспечение продовольственной безопасности страны. Это Мурманская и Магаданская области, Ненецкий, Ямало-Ненецкий, Чукотский автономные округа; Республики Тыва, Карелия и Ингушетия.

Результаты исследования. Начиная с 2012 г. страхование сельскохозяйственных рисков на основе государственной поддержки осуществлялось в соответствии с Федеральным законом от 25 июля 2011 г. № 260-Ф3 «О государственной поддержке в сфере сельскохозяйственного страхования и о внесении изменений в Федеральный закон „О развитии сельского хозяйства“"», и демонстрировало положительную динамику до 2014 г. Однако ввиду нерешенных до конца проблем в отрасли начиная с 2015 г. стали проявляться негативные тенденции. Во многом они были обусловлены фрагментарностью институциональной среды и преобразованиями, связанными с совершенствованием нормативно-правового и методологического поля, появлением новых институциональных структур.

Согласно данным федерального статистического наблюдения в 2016 г. среди регионов-лидеров по посевной (посадочной) площади, таких как Ставропольский и Краснодарский края, Республика Татарстан, Воронежская область, удельный вес посевных (посадочных) площадей застрахованных культур составил чуть более 10 \%. В Алтайском крае, Оренбургской, Саратовской и Ростовской областях было застраховано менее 6 \% посевных площадей. На рис. 2 видно, что максимальный целевой показатель был зафиксирован в Приморском крае, посевная (посадочная) площадь которого составляет всего 434,7 тыс. га. Удельный вес в сельскохозяйственной отрасли занимает подотрасль растениеводства $(83,7 \%)$, в которой занято более $70 \%$ К(Ф)Х и $50 \%$ сельскохозяйственных организаций. В данном субъекте в 2016 г. было застраховано 116 хозяйств, на 1 застрахованное хозяйство пришлось 1,2 тыс. га, со страховой суммой на 1 договор 18 798,9 тыс. руб.

Следующая волна институциональных изменений была связана с установлением нового порядка предоставления и распределения субсидий в сфере АПК из федерального бюджета бюджетам субъектов Российской Федерации, 
в соответствии с которым средства выделялись общей суммой в виде «единой субсидии», в состав которой вошли, в том числе, и средства на поддержку агрострахования $[12,13]$. Поскольку право распределения средств субсидии предоставлено регионам, место в системе приоритетов и расходы на агрострахование выделялись по остаточному принципу, что привело к снижению целевого индикатора - удельного веса посевной (посадочной) площади застрахованных культур до 1,7 \% в 2017 г. (рис. 3).

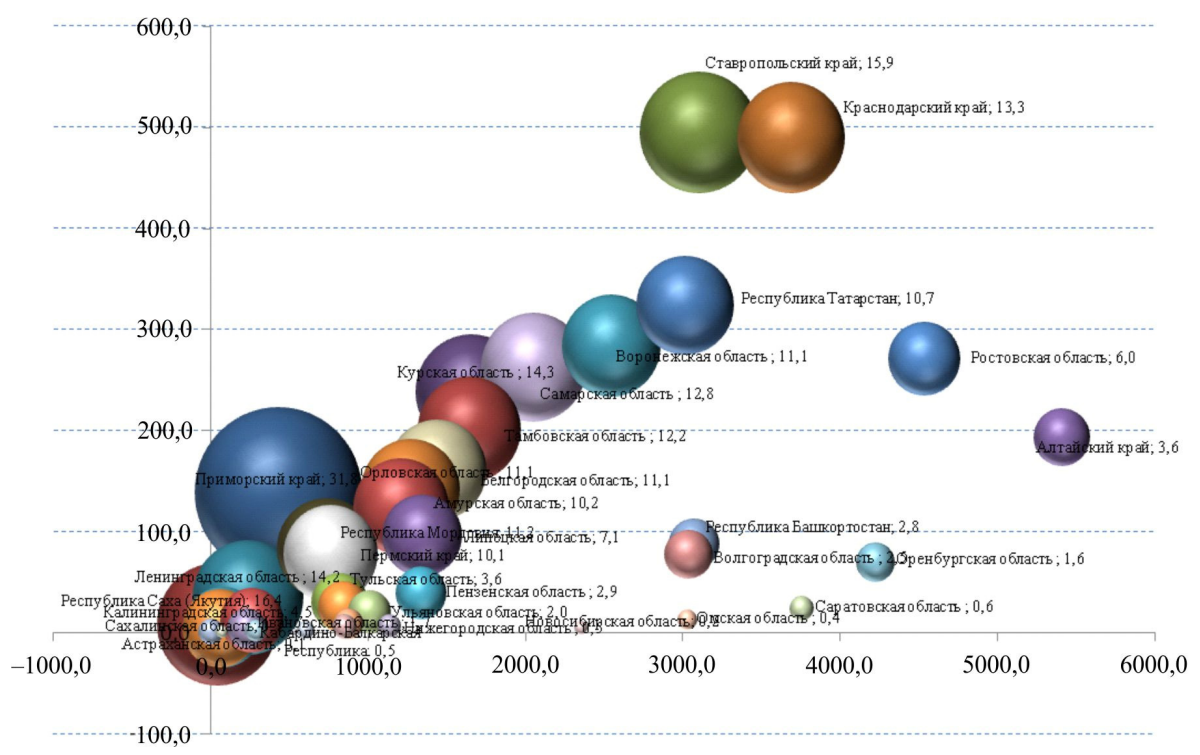

Рис. 2. Удельный вес посевной площади застрахованных культур в 2016 г., \% [11]

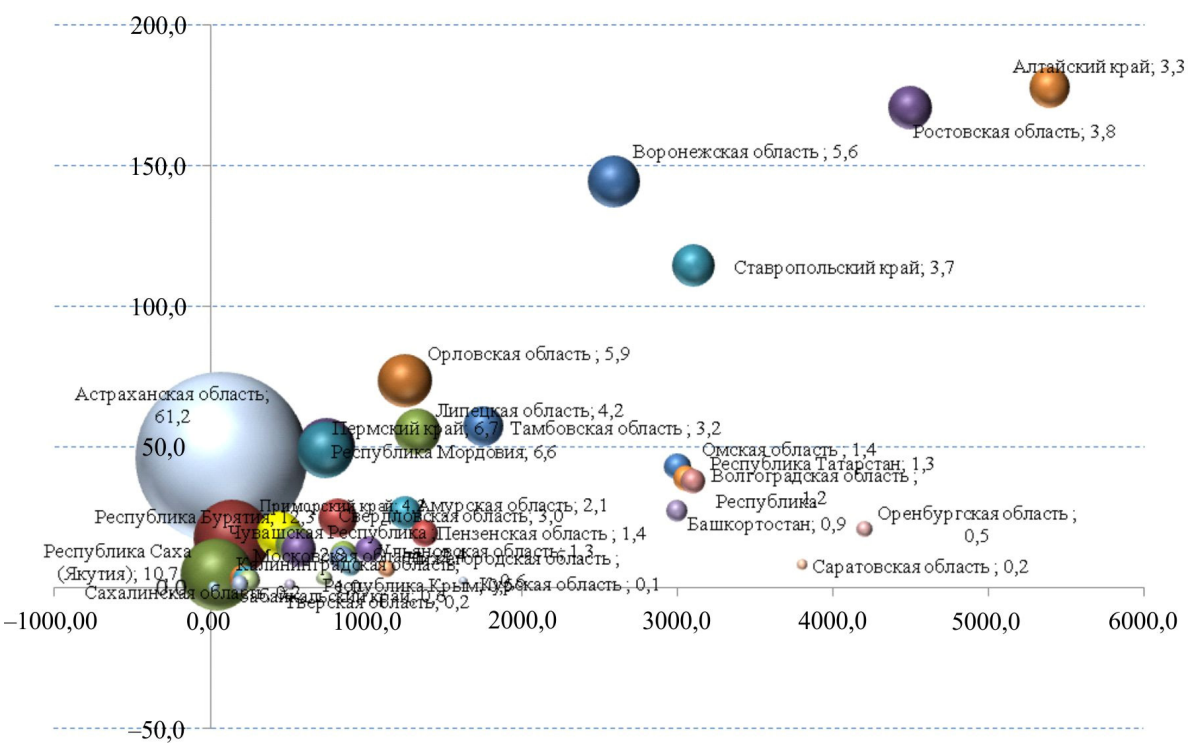

Рис. 3. Удельный вес посевной площади застрахованных культур в 2017 г., \% 
В 2017 г. значительным образом отличаются показатели сельскохозяйственного страхования с государственной поддержкой в растениеводческой подотрасли от предыдущих лет, а также причинно-следственная связь между ними. На основании данных выборочного федерального статистического наблюдения и данных Министерства сельского хозяйства РФ построена типологизация регионов РФ по целевому показателю. В результате получены 4 классификационные группы регионов РФ, численность и состав которых представлены в табл. 1 .

Таблица 1

Классификация субъектов РФ по удельному весу посевной площади застрахованных культур в 2017 г.

\begin{tabular}{|c|c|c|c|}
\hline $\begin{array}{c}\text { Номер } \\
\text { группы }\end{array}$ & \begin{tabular}{l|} 
Число \\
реги- \\
онов
\end{tabular} & $\begin{array}{c}\text { Средние } \\
\text { по группе } \\
\text { значения } \\
\text { показателя }\end{array}$ & Состав групп \\
\hline & 72 & 1,7 & Российская Федерация \\
\hline 1 & 14 & 5,4 & $\begin{array}{l}\text { Республики: Бурятия, Мордовия, Саха (Якутия), Чувашская. } \\
\text { Области: Орловская, Воронежская, Липецкая, } \\
\text { Ростовская, Тамбовская, Свердловская. } \\
\text { Края: Пермский, Приморский, Ставропольский, Алтайский }\end{array}$ \\
\hline 2 & 12 & 1,7 & $\begin{array}{l}\text { Республики: Татарстан. Области: Московская, Амурская, } \\
\text { Ивановская, Омская, Пензенская, Брянская, } \\
\text { Ульяновская, Ленинградская, Тульская, Волгоградская, } \\
\text { Калининградская }\end{array}$ \\
\hline 3 & 10 & 0,5 & $\begin{array}{l}\text { Республики: Башкортостан, Крым. } \\
\text { Области: Рязанская, Нижегородская, Оренбургская, } \\
\text { Тверская, Сахалинская, Саратовская, Курская. } \\
\text { Края: Забайкальский }\end{array}$ \\
\hline 4 & 36 & 0 & $\begin{array}{l}\text { Республики: Коми, Адыгея, Калмыкия, Дагестан, } \\
\text { Кабардино-Балкарская, Карачаево-Черкесская, Северная } \\
\text { Осетия-Алания, Чеченская, Марий Эл, Удмуртская, } \\
\text { Алтай, Хакасия. } \\
\text { Области: Белогородская, Владимирская, Калужская, } \\
\text { Костромская, Смоленская, Ярославская, Архангельская, } \\
\text { Вологодская, Новгородская, Псковская, Кировская, } \\
\text { Самарская, Курганская, Тюменская, Челябинская, } \\
\text { Иркутская, Кемеровская, Новосибирская, Томская. } \\
\text { Края: Краснодарский, Красноярский, } \\
\text { Камчатский, Хабаровский. } \\
\text { Автономные округа: Ханты-Мансийский }\end{array}$ \\
\hline
\end{tabular}

* Составлено автором на основе данных статистических сборников: Регионы России. Социально-экономические показатели. 2018; Продукция сельского хозяйства в 2013-2018 гг. [14]; данных министерств сельского хозяйства регионов РФ [15]; данных Федерального агентства по государственной поддержке агропромышленного комплекса [16]. 
Из-за внесения изменений в систему субсидирования в 2017 г. произошло значительное снижение показателей в страховании с господдержкой практически по всем регионам-лидерам по посевным (посадочным) площадям и производства продукции растениеводства. Более чем в 70 \% регионов РФ, доля сельского хозяйства в ВРП которых составляет более $10 \%$, не было включено страхование сельскохозяйственных рисков в растениеводстве и животноводстве в ряд приоритетных направлений развития регионального АПК.

Представленная в табл. 2 матрица парных коэффициентов корреляции между показателями сельскохозяйственного страхования с государственной поддержкой и отдельных экономических показателей сельскохозяйственного производства дает весьма многостороннюю характеристику эффективности работы данной системы в 2017 г. Исключая тесную связь между взаимозависимыми показателями, можно проследить, что удельный вес посевных (посадочных) площадей застрахованных культур и количество хозяйств, заключивших договоры страхования в 2017 г., значительным образом зависят от размера выделяемых бюджетных субсидий. Прослеживается зависимость между сальдированным финансовым результатом подотрасли растениеводства в 2017 г. и страховыми выплатами за предыдущий год, что подтверждает значимость данного механизма в формировании финансовой устойчивости агропроизводителей.

Средние значения показателей, характеризующих сельскохозяйственное страхование с государственной поддержкой, полученные по результатам кластерного анализа, представлены в табл. 3.

Анализ полученных результатов показывает следующее. Осуществление страхования посевных площадей в 2017 г. наиболее активно происходило в регионах первой классификационной группы. Среди лидеров страхования в 2017 г. Республики Бурятия и Саха (Якутия) с общей посевной (посадочной) площадью менее 200 тыс. га. На фоне общих тенденций существенным образом выделилась Астраханская область, удельный вес застрахованной посевной (посадочной) площади составил 61,2 \%. В целях осуществления объективного анализа она не включена в выборку. Для Астраханской области агрострахование подотрасли растениеводства является недостаточно востребованным экономическим механизмом ввиду специфики региона, преобладания рыбной отрасли в структуре ВРП. Общая посевная площадь области всего 81,6 тыс. га. Развитие в области получило мелкотоварное сельскохозяйственное производство, которое обеспечивают малые формы хозяйствования К(Ф)Х и ЛПХ $[17,18]$. Вероятно, высокие показатели агрострахования с господдержкой обусловлены внутренними приоритетами и агропродовольственной политикой региона. Высокие показатели размера посевных (посадочных) площадей и выделяемых бюджетных субсидий обеспечивают вошедшие в данную группу Ставропольский край, Ростовская и Воронежская области. 
즐

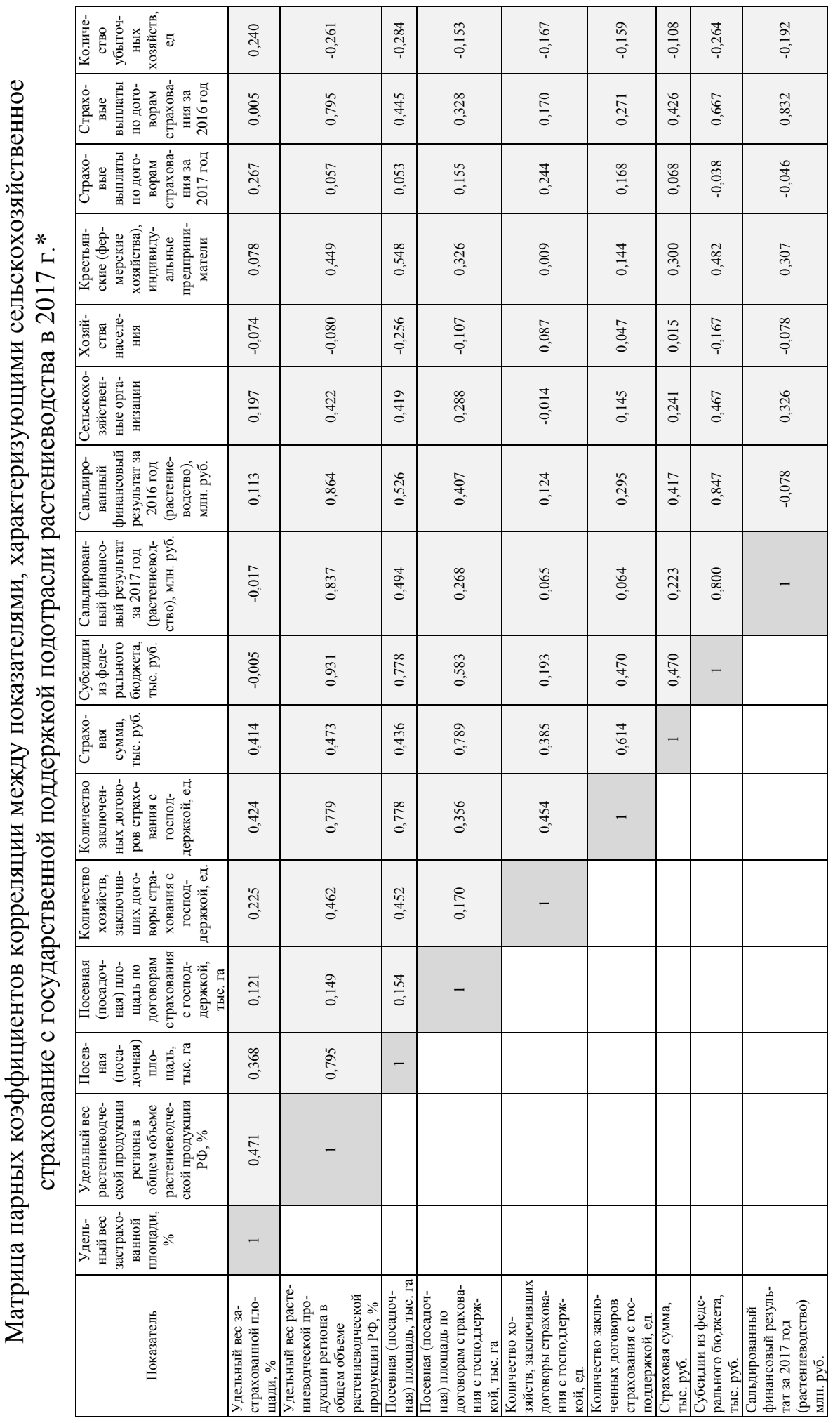


공

\begin{tabular}{|c|c|c|c|c|c|c|}
\hline 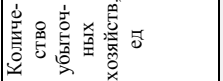 & $\stackrel{5}{\underline{i}}$ & 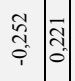 & $\begin{array}{l}\infty \\
0 \\
0 \\
0\end{array}$ & $\begin{array}{l}n \\
\hat{o} \\
i\end{array}$ & $\frac{\circ}{i}$ & - \\
\hline 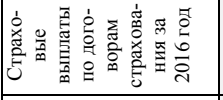 & $\begin{array}{c}\frac{\infty}{0} \\
0 \\
0 \\
0\end{array}$ & \begin{tabular}{ll|}
0 & 0 \\
0 \\
0 \\
0 \\
0 \\
0
\end{tabular} & ป̂ & స̂. & - & \\
\hline 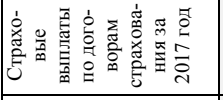 & $\begin{array}{l}\text { 总 } \\
\text { i. }\end{array}$ & 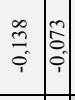 & $\begin{array}{l}\equiv \\
\bar{i}\end{array}$ & - & & \\
\hline 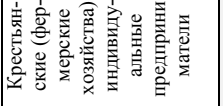 & $\begin{array}{l}\infty \\
\infty \\
0 \\
0\end{array}$ & 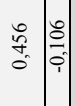 & - & & & \\
\hline 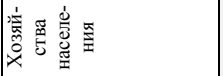 & $\begin{array}{l}\infty \\
\tilde{\delta} \\
i \\
i\end{array}$ & \begin{tabular}{c|c}
\multirow{j}{*}{} & -1 \\
i & -1
\end{tabular} & & & & \\
\hline 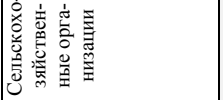 & 袁 & - & & & & \\
\hline 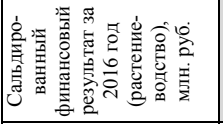 & - & & & & & \\
\hline 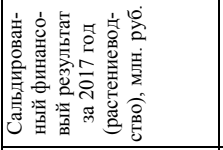 & & & & & & \\
\hline 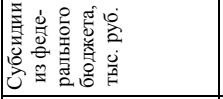 & & & & & & \\
\hline 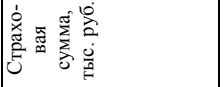 & & & & & & \\
\hline 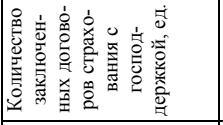 & & & & & & \\
\hline 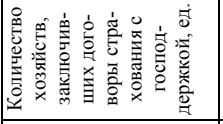 & & & & & & \\
\hline 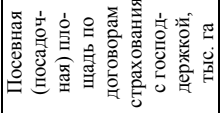 & & & & & & \\
\hline 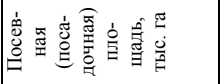 & & & & & & \\
\hline 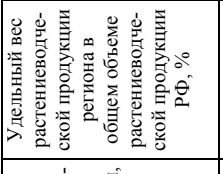 & & & & & & \\
\hline 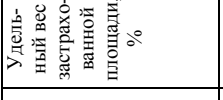 & & & & & & \\
\hline 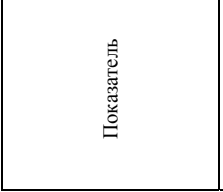 & 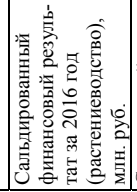 & 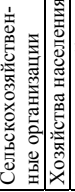 & $\begin{array}{l}\text { D. } \\
\end{array}$ & 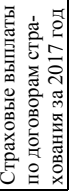 & 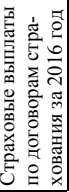 & 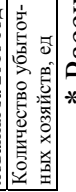 \\
\hline
\end{tabular}


Средние по квалификационным группам значения показателей сельскохозяйственного страхования с государственной поддержкой за 2017 г.*

\begin{tabular}{|c|c|c|c|c|c|c|c|}
\hline $\begin{array}{c}\text { Номер } \\
\text { группы }\end{array}$ & $\begin{array}{c}\text { Удельный вес } \\
\text { растение- } \\
\text { водческой } \\
\text { продукции } \\
\text { региона в } \\
\text { общем объеме } \\
\text { растениевод- } \\
\text { ческой про- } \\
\text { дукции РФ, \% }\end{array}$ & $\begin{array}{c}\text { Посевная } \\
\text { (посадоч- } \\
\text { ная) } \\
\text { площадь, } \\
\text { тыс. га }\end{array}$ & $\begin{array}{c}\text { Посевная } \\
\text { (посадоч- } \\
\text { ная) пло- } \\
\text { щадь по } \\
\text { договорам } \\
\text { страхова- } \\
\text { ния с гос- } \\
\text { поддерж- } \\
\text { кой, тыс га }\end{array}$ & $\begin{array}{c}\text { Страховая } \\
\text { сумма на } \\
\text { договор } \\
\text { страхо- } \\
\text { вания, } \\
\text { тыс. руб. }\end{array}$ & $\begin{array}{c}\text { Страховая } \\
\text { сумма на } \\
\text { одно } \\
\text { застра- } \\
\text { хованное } \\
\text { хозяйство, } \\
\text { тыс. руб. }\end{array}$ & $\begin{array}{c}\text { Сальдиро- } \\
\text { ванный } \\
\text { финансо- } \\
\text { вый ре- } \\
\text { зультат } \\
\text { подотрас- } \\
\text { ли расте- } \\
\text { ниевод- } \\
\text { ства, тыс. } \\
\text { руб. }\end{array}$ & $\begin{array}{c}\text { Выделенные } \\
\text { субсидии на } \\
\text { сельско- } \\
\text { хозяй- } \\
\text { ственное } \\
\text { страхование } \\
\text { в подотрасли } \\
\text { растениевод- } \\
\text { ства, тыс. } \\
\text { руб. }\end{array}$ \\
\hline 1 & 2,1 & 1675,1 & 68,6 & 100372,9 & 245486,4 & 1796,4 & 121871,1 \\
\hline 2 & 1,6 & 1316,6 & 21,8 & 134911,0 & 133352,9 & 583,5 & 67048,0 \\
\hline 3 & 1,3 & 1614,8 & 5,4 & 161893,3 & 80013,5 & 307,0 & 77728,0 \\
\hline 4 & 0,9 & 665,2 & 0 & 0 & 0 & 896,9 & 44135,9 \\
\hline $\begin{array}{l}\text { В сред- } \\
\text { нем по } \\
\text { РФ }\end{array}$ & 1,4 & 1098,4 & 17,7 & 55719,4 & 81071,9 & 937,7 & 67735,3 \\
\hline
\end{tabular}

* Рассчитано автором.

Средние значения второй классификационной группы наиболее приближены к средним значениям по Российской Федерации. Сюда вошли как регионы с посевными площадями более 3 млн га (Республика Татарстан, Омская и Волгоградская области), так и регионы с посевной площадью менее 1 млн га (Ивановская область, Московская, Тульская области, Республика Чувашия). При этом средняя посевная (посадочная) площадь застрахованных культур в регионах данной группы не превышает 21 тыс. га, что говорит о недостаточной объективности результирующего показателя субсидируемого агрострахования. Для субъектов с низким показателем посевных площадей, даже небольшой объем застрахованной площади дает высокий процент результирующего показателя, что искажает представление об эффективности сельскохозяйственного страхования в масштабе страны.

Средняя посевная (посадочная) площадь субъектов, входящих в третью классификационную группу, составляет 1614,8 тыс. га, при этом средняя посевная (посадочная) площадь застрахованных культур в 4 раза меньше аналогичного показателя второй классификационной группы. Очевидно, что средний размер выделенных на агрострахование бюджетных субсидий наименыший из выделенных нами четырех групп - 77728 тыс. руб., а вот средняя страховая сумма на 1 договор страхования максимальная - 161 893,3 тыс. руб.

В четвертую классификационную группу вошли регионы с посевной (посадочной) площадью менее 1000 тыс. га и удельным весом продукции 
растениеводства в общем объеме растениеводческой продукции по РФ менее $1 \%$. Исключение составил только лидер в стране по производству продукции растениеводства (10\%) Краснодарский край (3658,2 тыс. га), который в 2017 г. полностью отказался от агрострахования. Показатели страхования в данной классификационной группе нулевые, однако сальдированный финансовый результат превышает аналогичный показатель второй и третьей классификационных групп.

Неопределенность с получением субсидий, отсутствие масштабных потерь урожая в 2014-2017 гг. не способствовали желанию сельхозпроизводителей заключать договоры страхования и в 2018 г., в котором было принято на субсидирование 334 договора страхования. Посевная (посадочная) площадь по договорам страхования урожая сельскохозяйственных культур составила всего 1182,1 тыс. га, или 1,5 \% от всей посевной (посадочной) площади. Страховая сумма и начисленная страховая премия 988,8 млн руб. Средний размер страхового тарифа $-4,1 \%$. Доля застрахованной стоимости продукции растениеводства (страховая сумма по договорам сельскохозяйственного страхования) в общем объеме стоимости продукции растениеводства 1,5 \% (целевой показатель - 15,5\%), невыполнение связано с тем, что фактический объем производства продукции растениеводства значительно превысил расчетные плановые значения, а объем застрахованной продукции растениеводства уменьшился [8] (рис. 4).

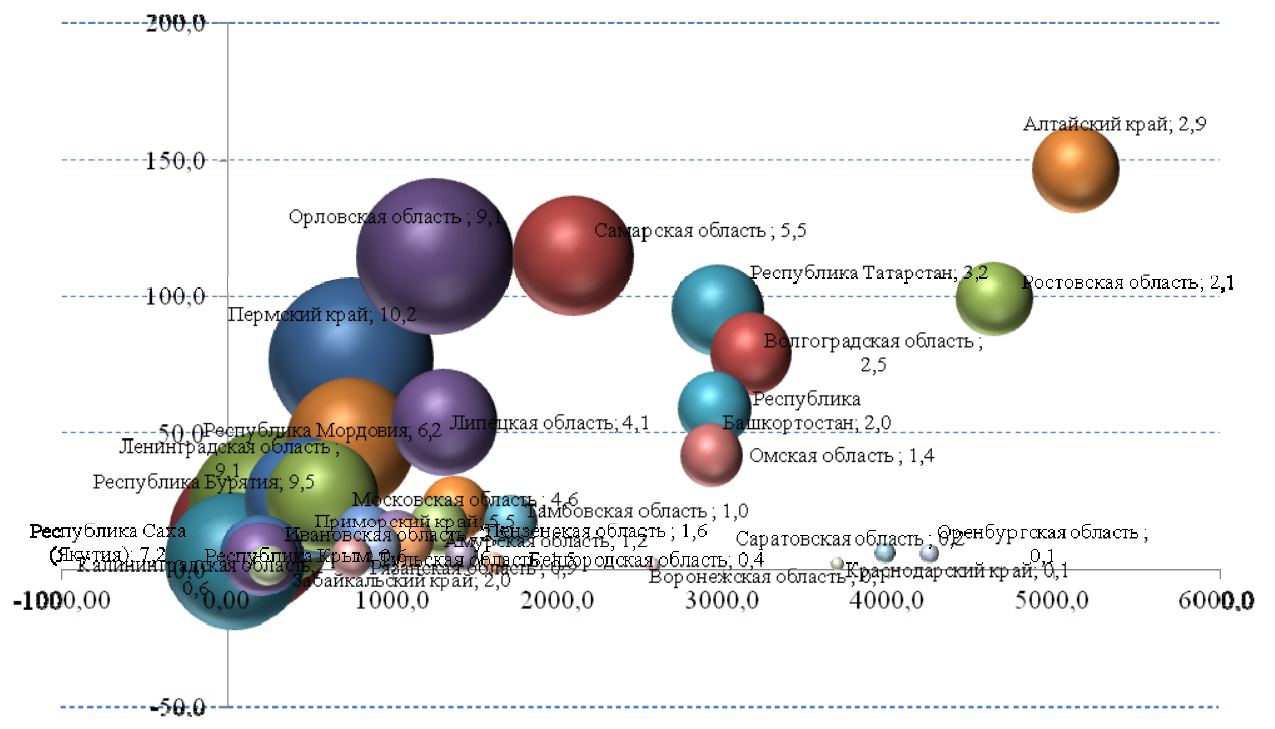

Рис. 4. Удельный вес посевной площади застрахованных культур в 2018 г., \%

Несмотря на то, что в 2018 г. в структуре приоритетов развития сельского хозяйства в субъектах РФ прослеживалась более позитивная тенденция включения страхования сельскохозяйственных рисков в подотраслях расте- 
ниеводства и животноводства, как и в 2017 г. отказались от страхования подотрасли растениеводства такие регионы, как Волгоградская, Саратовская, Белгородская, Оренбургская, Липецкая области, Алтайский край, удельный вес растениеводческой продукции которых в общем объеме растениеводческой продукции по РФ составляет от 2,5 до $5 \%$, а также Краснодарский край $(10 \%)$.

На протяжении последних лет эффект от принятых мер государственного стимулирования развития агрострахования можно отметить в регионах, входящих в перечень субъектов Российской Федерации, территории которых относятся в соответствии с Распоряжением Правительства Российской Федерации от 26 января 2017 г. № 104-р к неблагоприятным для производства сельскохозяйственной продукции территориям [19]. Удельный вес посевной (посадочной) площади застрахованных культур отмечен в регионах с наименьшими посевными площадями по РФ и был обусловлен предоставленной повышенной погектарной поддержкой, выделением региональных бюджетных субсидий на субсидирование договоров страхования. Одним из наиболее ярких примеров в 2018 г. можно привести Республику Саха (Якутия) - 7,2 \% застрахованной посевной площади. Однако при общей посевной площади в 47,2 тыс. га этот показатель составил лишь 3,4 тыс. га, при том, что в подотрасли растениеводства заняты преимущественно хозяйства населения. Несмотря на то, что ежегодно в регионе застраховано около $10 \%$ посевных площадей, с 2017 г. правительство республики увеличило долю бюджетного субсидирования в оплате страхового взноса, поэтому начиная с 2018 г., сельхозтоваропроизводители получают почти 95 \% стоимости страхования.

Bblводы. Территориальный дисбаланс сельскохозяйственного страхования обусловлен многими причинами, в том числе различным промышленным, аграрным, природно-климатическим, трудовым потенциалом; концентрацией административных, финансовых и деловых ресурсов. Проведенное исследование позволило сделать вывод о том, что реализация программ агрострахования, осуществляемого с государственной поддержкой, в первую очередь зависит от внутренних стратегических приоритетов и агропродовольственной политики региона. Поэтому разработку стратегических документов, определяющих вектор развития системы сельскохозяйственного страхования, необходимо осуществлять с учетом основных особенностей и потребностей развития региональных агросистем [20, с. 18$]$.

Для преодоления высокой региональной дифференциации в агростраховании с государственной поддержкой необходимо последовательное устранение институциональных барьеров, препятствующих сбалансированной работе страховой системы; включение субсидируемого агрострахования в список приоритетных направлений развития сельского хозяйства субъектов РФ, а также региональных программ социального и экономического развития. 
Кроме того, считаем необходимым внесение коррективов в Стратегию развития страховой отрасли Российской Федерации на 2019-2021 гг. в направлении учета региональной специфики. В данной Стратегии в п. 2.3 списка предусмотренных мер по расширению проникновения рынка страхования в агропромышленный комплекс, приоритетными являются только: выделение бюджетных субсидий на сельскохозяйственное страхование в качестве самостоятельного направления в рамках подпрограммы «Обеспечение общих условий функционирования отраслей агропромышленного комплекса»; придание «защищенного» статуса субсидиям на страхование сельскохозяйственных рисков подотраслей растениеводства и животноводства в рамках «единой» субсидии вплоть до их выведения из ее состава; внесение поправок в Федеральный закон от 25.07.2011 № 260-Ф3 в целях обеспечения гибкости условий государственной поддержки; разработка специальных страховых программ для отдельных подотраслей АПК, в том числе с использованием индексного страхования [21]. Лишь в действующей Стратегии развития страховой деятельности в Российской Федерации до 2020 г. упомянута необходимость регионального развития, в частности касающаяся расширения региональных программ развития отдельных видов страхования с учетом географической, отраслевой, природно-климатической и демографической специфики субъектов РФ, региональной специфики деятельности обществ взаимного страхования (ОВС). Одним из принципов совершенствования системы сельхозстрахования является вариативность условий агрострахования с господдержкой с учетом региональной специфики агросистем: сельхозтоваропроизводителей, климатических зон, состояния почв, агротехники и рискованности деятельности и т.д. [22].

\section{Список литературы}

1. Былина С.Г., Кадомцева М.Е., Осовин М.Н. Информатизация агропродовольственного комплекса и сельских территорий России: возможности и ограничения: моногр. - Саратов: Саратовский источник, 2018. - 228 с.

2. Модели и результаты прогнозирования динамики цен на продукцию зернопродуктового подкомплекса / Р.П. Кутенков, С.Г. Былина, М.Н. Осовин, В.Л. Шабанов // Региональные агросистемы: экономика и социология. - 2008. № $1 .-$ C. 78 .

3. Национальная продовольственная безопасность России: стратегические приоритеты и условия обеспечения / А.А. Анфиногентова, М.Ю. Мореханова, Т.В. Блинова, С.А. Андрющенко [и др.]. - Саратов: Саратовский источник, 2018. - 413 с.

4. Крылатых Э.Н. Проблема экономических рисков в агропромышленном комплексе // Проблемы прогнозирования. - 1999. - № 5. - С. 81. 
5. Коростелев В.Г., Кадомцева М.Е. Агрострахование как элемент климатически оптимизированного сельского хозяйства // Международный сельскохозяйственный журнал. - 2018. - № 5 (365). - С. 39-43.

6. О системных мерах, направленных на предотвращение и снижение потерь от чрезвычайных ситуаций в субъектах Российской Федерации [Электронный ресурс] // Офиц. сайт М-ва чрезв. ситуаций РФ. - URL: http:/www.mchs.gov.ru/upload/site1/document_file/9GMXaeYjhw.pdf (дата обращения: 12.04.2019).

7. Оперативная информация о текущей ситуации в сельскохозяйственном страховании с государственной поддержкой [Электронный ресурс]. URL:http://fagps.ru/ (дата обращения: 23.04.2019).

8. Итоговый доклад о результатах деятельности Минсельхоза России за 2018 года [Электронный ресурс]. - URL: http://mcx.ru/upload/iblock/10c/ 10c6695082afd0ac0ea4b6e41fa3f6d9.pdf (дата обращения: 06.05.2019).

9. Алтухов А.И. Межрегиональный обмен в системе продовольственного обеспечения страны // Экономика сельского хозяйства России. - 2017. № 1. - С. 61-70.

10. Яковенко Н.А., Иваненко И.С. Региональная дифференциация в развитии мясопродуктовой цепочки агропродовольственного комплекса России [Электронный ресурс] // Региональные агросистемы: экономика и социология. - 2017. - № 3. - URL: http:/www.iagpran.ru/datas/users/3438c524d6500e 5de308ee52452f01cb.pdf (дата обращения: 02.05.2019).

11. Регионы России. Социально-экономические показатели. 2018: стат. сб. / Росстат. - М., 2018. - 1162 с.

12. О федеральном бюджете на 2017 год и на плановый период 2018 и 2019 годов [Электронный ресурс]: Федер. закон от 19.12.2016 № 415-Ф3. URL: http://base.garant.ru/71570266/ (дата обращения: 26.03.2019).

13. Правила предоставления и распределения субсидий из федерального бюджета бюджетам субъектов Российской Федерации на содействие достижению целевых показателей региональных программ развития агропромышленного комплекса [Электронный ресурс]: приложение № 9 к Гос. программе развития сельского хозяйства и регулирования рынков сельскохозяйственной продукции, сырья и продовольствия на 2013-2020 гг., утв. Постановлением Правительства Российской Федерации от 14.07.2012 № 717 «О Государственной программе развития сельского хозяйства и регулирования рынков сельскохозяйственной продукции, сырья и продовольствия на 2013-2020 годы». URL: http://www.garant.ru/products/ipo/prime/doc/71660580/ (дата обращения: 14.05.2019).

14. Продукция сельского хозяйства по субъектам Российской Федерации. 2013, 2014, 2015, 2016, 2017 [Электронный ресурс]. - URL: www.gks.ru/ free_doc/doc_2016/bul_dr/sx/sxprod2017.xls (дата обращения: 11.04.2019). 
15. Распределение «единой» субсидии между бюджетами субъектов Российской Федерации на 2017 год и на плановый период 2018 и 2019 годов [Электронный ресурс] // Офиц. сайт М-ва сел. хоз-ва Рос. Федерации. URL:http://www.mcx.ru (дата обращения: 18.03.2019).

16. Сводные статистические данные по страхованию урожая сельскохозяйственных культур, урожая и посадок многолетних насаждений и сельскохозяйственных животных с государственной поддержкой в 2013-2017 гг. [Электронный ресурс] // Офиц. сайт Федер. агентства по гос. поддержке агропром. комплекса. - URL: http://www.fagps.ru/ (дата обращения: 21.05.2019).

17. О государственной программе «Развитие сельского хозяйства, пищевой и рыбной промышленности Астраханской области» (с изм. на 21 сент. 2018 г.) [Электронный ресурс]: постановление правительства Астраханской области от 10 сент. 2014 г. № 368-П. - URL: http://docs.cntd.ru/document/ 428588456 (дата обращения: 29.03.2019).

18. Бурлаков В.Б. Проблемы развития страхования рисков сельскохозяйственного производства на кооперативной основе // Научное обозрение: теория и практика. - 2018. - № 8. - С. 136-146.

19. Об утверждении перечня субъектов Российской Федерации, территории которых относятся к неблагоприятным для производства сельскохозяйственной продукции территориям [Электронный ресурс]: распоряжение Правительства Российской Федерации от 26 янв. 2017 г. № 104-p. - URL: http://docs.cntd.ru/document/456038774 (дата обращения: 15.05.2019).

20. Осовин М.Н. Обоснование приоритетных направлений повышения конкурентоспособности России в условиях новых глобальных вызовов // Экономика: теория и практика. - 2016. - № 3 (43). - С. 15-20.

21. О государственной поддержке в сфере сельскохозяйственного страхования и о внесении изменений в Федеральный закон «О развитии сельского хозяйства» [Электронный ресурс]: Федер. закон от 25.07.2011 № 260-Ф3. URL: http://www.consultant.ru/document/cons_doc_LAW_117362/ (дата обращения: 06.05.2019).

22. Стратегия развития страховой деятельности в Российской Федерации до 2020 года [Электронный ресурс]: утв. Распоряжением Правительства Российской Федерации от 22 июля 2013 г. № 1293-p. - URL: http://static. government.ru/media/files/41d47e4f03ae8a61bd97.pdf (дата обращения: 27.07.2019).

\section{References}

1. Bylina S.G., Kadomtseva M.E., Osovin M.N. Informatizatsiia agroprodovol'stvennogo kompleksa i sel'skikh territorii Rossii: vozmozhnosti i ogranicheniia [Informatization of the agricultural sector and rural territories of Russia: Opportunities and limitations]. Saratov, Saratovskii istochnik, 2018, 228 p. 
2. Kutenkov R.P., Bylina S.G., Osovin M.N., Shabanov V.L. Modeli i rezul'taty prognozirovaniia dinamiki tsen na produktsiiu zernoproduktovogo podkompleksa [Models and forecasting results of price movements for products of grain products subcomplex]. Regional'nye agrosistemy: ekonomika i sotsiologiia, 2008, no. 1, p. 78, available at: http://www.iagpran.ru/datas/users/443ed8e0fd13 b3860c5c6f943d016de5.pdf (accessed 22 March 2019).

3. Anfinogentova A.A., Morekhanova M.Iu., Blinova T.V., Andriushchenko S.A. [et al.]. Natsional'naia prodovol'stvennaia bezopasnost' Rossii: strategicheskie prioritety i usloviia obespecheniia [National food security of Russia: Strategic priorities and conditions for ensuring]. Ed. T.V. Blinova. Saratov, Saratovskii istochnik, 2018, 413 p.

4. Krylatykh E.N. Problema ekonomicheskikh riskov v agropromyshlennom komplekse [The problem of economic risks in the agricultural sector]. Zhurnal Agrarnoi ekonomiki i marketinga, 2002, no. 1, available at: http://agriterra.net/ section/19.aspx (accessed 31 March 2019).

5. Korostelev V.G., Kadomtseva M.E. Agrostrakhovanie kak element klimaticheski optimizirovannogo sel'skogo khoziaistva [Agricultural insurance as an element of climate-smart agriculture]. Mezhdunarodnyi sel'skokhoziaistvennyi zhurnal, 2018, no. 5(365), pp. 39-43.

6. O sistemnykh merakh, napravlennykh na predotvrashchenie i snizhenie poter' ot chrezvychainykh situatsii v sub"ektakh Rossiiskoi Federatsii [On systemic measures aimed at preventing and reducing losses from emergency situations in the entities of the Russian Federation]. Available at: http:/www.mchs.gov.ru/ upload/site1/document_file/9GMXaeYjhw.pdf (accessed 12 April 2019).

7. Operativnaia informatsiia o tekushchei situatsii v sel'skokhoziaistvennom strakhovanii s gosudarstvennoi podderzhkoi [Operative information on the current situation in agricultural insurance with state support]. Available at: http://fagps.ru/ (accessed 23 April 2019).

8. Itogovyi doklad o rezul'tatakh deiatel'nosti Minsel'khoza Rossii za 2018 god [2018 Final performance report of the Ministry of Agriculture of Russia]. Available at: http://mcx.ru/upload/iblock/10c/10c6695082afd0ac0ea4b6e41f a3f6d9.pdf (accessed 06 May 2019).

9. Altukhov A.I. Mezhregional'nyi obmen v sisteme prodovol'stvennogo obespecheniia strany [Interregional exchange in the country's food system]. Ekonomika sel'skogo khoziaistva Rossii, 2017, no. 1, pp. 61-70.

10. Iakovenko N.A., Ivanenko I.S. Regional'naia differentsiatsiia v razvitii miasoproduktovoi tsepochki agroprodovol'stvennogo kompleksa Rossii [Regional differentiation in the development of the meat product chain of the agro-food complex of Russia]. Regional'nye agrosistemy: ekonomika i sotsiologiia, 2017, no. 3, available at: http://www.iagpran.ru/datas/users/3438c524d6500e5de308ee 52452f01cb.pdf (accessed 02 May 2019). 
11. Regiony Rossii. Sotsial'no-ekonomicheskie pokazateli [Regions of Russia. Socio-economic indicators]. Moscow, Rosstat, 2018, 1162 p.

12. O federal'nom biudzhete na 2017 god i na planovyi period 2018 i 2019 godov [On Federal budget for 2017 and a planning period of 2018 and 2019]. Federal Law of Dec. 19, 2016 no. 415-FZ, available at: http://base.garant.ru/71570266/ (accessed 26 March 2019).

13. Pravila predostavleniia i raspredeleniia subsidii iz federal'nogo biudzheta biudzhetam sub"ektov Rossiiskoi Federatsii na sodeistvie dostizheniiu tselevykh pokazatelei regional'nykh programm razvitiia agropromyshlennogo kompleksa [Elektronnyi resurs]: prilozhenie № 9 k Gos. programme razvitiia sel'skogo khoziaistva i regulirovaniia rynkov sel'skokhoziaistvennoi produktsii, syr'ia i prodovol'stviia na 2013-2020 gg., utv. Postanovleniem Pravitel'stva Rossiiskoi Federatsii ot 14.07.2012 № 717 «O Gosudarstvennoi programme razvitiia sel'skogo khoziaistva i regulirovaniia rynkov sel'skokhoziaistvennoi produktsii, syr'ia i prodovol'stviia na 2013-2020 gody» [Rules of granting and distribution of subsidies from the Federal budget to budgets of subjects of the Russian Federation for assistance in achievement of target indicators of regional programs of development of an agroindustrial complex. Appendix No. 9 to the State program of development of agriculture and regulation of markets of agricultural production, raw materials and food for 2013-2020 approved by the Resolution of the Government of the Russian Federation of July 14, 2012 no. 717 On the State program for the development of agriculture and regulation of markets for agricultural products, raw materials and food for 2013-2020. Available at: http://www.garant.ru/ products/ipo/prime/doc/71660580/ (accessed 14 May 2019).

14. Produktsiia sel'skogo khoziaistva po sub"ektam Rossiiskoi Federatsii [Agricultural products in the entities of the Russian Federation]. 2013, 2014, 2015, 2016, 2017, available at: www.gks.ru/free_doc/doc_2016/bul_dr/sx/sxprod2017.xls (accessed 11April 2019).

15. Raspredelenie "edinoi" subsidii mezhdu biudzhetami sub"ektov Rossiiskoi Federatsii na 2017 god i na planovyi period 2018 i 2019 godov [Distribution of a general subsidy among the entities of the Russian Fedration in 2017 and forecast for 2018-2019]. Ministry of Agriculture of the Russian Federation. Available at: http://www.mcx.ru (accessed 18 March 2019).

16. Svodnye statisticheskie dannye po strakhovaniiu urozhaia sel'skokhoziaistvennykh kul'tur, urozhaia i posadok mnogoletnikh nasazhdenii i sel'skokhoziaistvennykh zhivotnykh s gosudarstvennoi podderzhkoi v 2013-2017 gg. [Summary statistics on insurance of crops, crops and plantings of perennial plantations and farm animals with state support in 2013-2017]. Federal Agency for State Support of Agriculture. Available at: http:/www.fagps.ru/ (accessed 21 May 2019).

17. O gosudarstvennoi programme "Razvitie sel'skogo khoziaistva, pishchevoi i rybnoi promyshlennosti Astrakhanskoi oblasti" [On the state program 
"Development of agriculture, food and fishing industry of the Astrakhan region"]. Decree of the Government of the Astrakhan region of Sep. 10, 2014 no. 368-P, rev. Sep. 21, 2018, available at: http://docs.cntd.ru/document/428588456 (accessed 29 March 2019).

18. Burlakov V.B. Problemy razvitiia strakhovaniia riskov sel'skokhoziaistvennogo proizvodstva na kooperativnoi osnove [Problems of development of agricultural production risk insurance on a cooperative basis]. Nauchnoe obozrenie: teoriia i praktika, 2018, no. 8, pp. 136-146.

19. Ob utverzhdenii perechnia sub"ektov Rossiiskoi Federatsii, territorii kotorykh otnosiatsia $\mathrm{k}$ neblagopriiatnym dlia proizvodstva sel'skokhoziaistvennoi produktsii territoriiam [On approval of the list of the entities of the Russian Federation with territories unfavorable for agricultural production]. Order of the Government of the Russian Federation of Jan. 26, 2017 no. 104-r, available at: http://docs.cntd.ru/document/456038774 (accessed 15 May 2019).

20. Osovin M.N. Obosnovanie prioritetnykh napravlenii povysheniia konkurentosposobnosti Rossii v usloviiakh novykh global'nykh vyzovov [Reasoning of priority areas for increasing Russia's competitiveness in the context of new global challenges]. Ekonomika: teoriia i praktika, 2016, no. 3(43), pp. 15-20.

21. O gosudarstvennoi podderzhke $\mathrm{v}$ sfere sel'skokhoziaistvennogo strakhovaniia $\mathrm{i}$ o vnesenii izmenenii v Federal'nyi zakon "O razvitii sel'skogo khoziaistva" [On state support in agricultural insurance and on amendments to the Federal law "On the development of agriculture"]. Federal Law of Jul. 25, 2011 no. 260-FZ, available at: http://www.consultant.ru/document/cons_doc_LAW_117362/ (accessed 06 May 2019).

22. Strategiia razvitiia strakhovoi deiatel'nosti v Rossiiskoi Federatsii do 2020 goda [Strategy for the development of insurance activity in the Russian Federation until 2020]. Approved by the Order of the Government of the Russian Federation of Jul. 22, 2013 no. 1293-r, available at: http://static.government.ru/media/ files/41d47e4f03ae8a61bd97.pdf (accessed 27 July 2019).

Оригинальность $77 \%$

Получено 19.06.2019 Принято 19.07.2019 Опубликовано 15.01.2020 
M.E. Kadomtseva

\section{RESEARCH OF INTERREGIONAL DIFFERENCES OF DEVELOPMENT OF AGRICULTURAL RISKS INSURANCE IN CROP PRODUCTION}

The fragmentation of the Russian economic system in the spatial aspect is one of the reasons hindering the development of the national agro-food complex. The most important element of this system is the agricultural risks insurance, including those carried out with the state support. The development of processes of subsidized agricultural risks insurance in the regions is very uneven. This problem is highly relevant since the task of food self-sufficiency of the country is strictly connected with the interregional space. Therefore, the purpose of this study is to analyze the regional characteristics of the development and level of use of agricultural risk insurance with state support, as well as to determine the factors determining the processes of regional differentiation. The main indicators characterizing agricultural insurance with state support from 2016 to 2018 are analyzed using the correlationregression method, and the causal relationship between insurance indicators, economic indicators of agricultural production, resource potential and budget subsidies of constituent entities of the Russian Federation is investigated. The analysis provided the basis for identifying the factors that have the greatest influence on the use of agricultural producers in the agricultural subsidized agricultural risks in crop production. It is proved the need to take into account the regional dimension in the development of a strategy for the development of agricultural insurance.

Keywords: insurance, agriculture, crop production, food security, subsidy, regional differentiation, mechanism.

Marina E. Kadomtseva - Candidate of Economic Sciences, Senior Researcher, Laboratory for the Strategy Development of the Institutional Environment of the Agro-Industrial Complex, Institute of Agrarian Problems of RAS, e-mail: kozyreva_marina_@mail.ru.

Received 19.06.2019 Accepted 19.07.2019 Published 15.01.2020 